\title{
Detection of Leishmania parasites in the testis of a dog affected by orchitis: case report
}

\author{
Laura Manna ${ }^{1 *}$, Orlando Paciello ${ }^{2}$, Rossella Della Morte ${ }^{3}$ and Angelo Elio Gravino ${ }^{1}$
}

\begin{abstract}
Background: Transmission of canine leishmaniasis (CanL), a severe infection caused by L. infantum, usually occurs through the sand fly bite to the vertebrate host. A venereal route of transmission has also been suggested, but this issue is still controversial.

Findings: Here, we report a case of a dog affected by orchitis showing a clinical profile of L. infantum infection. By exploiting a real-time PCR assay, we detected a significantly higher DNA load of the parasite in the lymph node and testis than in blood and urine samples collected from the dog.

Conclusions: Our results suggest that: 1) L. infantum infection can be associated with testicular lesions in naturally infected dogs; 2) genital involvement could result in shedding of the parasites in the semen, favoring venereal transmission of the disease.
\end{abstract}

Keywords: Dog, Leishmaniasis, Orchitis, Real-time PCR, Testis

\section{Findings}

Introduction

Canine leishmaniasis (CanL) is a severe sandfly-borne infection caused by the protozoan parasite Leishmania infantum (syn. L. chagasi) widely distributed in temperate and subtropical countries. The clinical manifestations of the disease range from unapparent subclinical infections to a systemic disease characterized by weight loss, lymphadenopathy, hemorrhagic diarrhea, ocular lesions, and hyperthermia, frequently associated also with dermatological lesions. Dogs are the main reservoir of $L$. infantum and they play a central role in the transmission of the disease to humans. The prevalence and the incidence of CanL have been underestimated until now $[1,2]$. Transmission of the disease usually occurs through the phlebotomine sand fly bite to the vertebrate host; however, CanL transmission through blood transfusion has been documented [3]. Recent evidence also suggests

\footnotetext{
* Correspondence: laumanna@unina.it

${ }^{1}$ Department of Veterinary Clinical Science, University of Naples Federico II, Via F. Delpino 1, 80137 Naples, Italy

Full list of author information is available at the end of the article
}

a venereal route of transmission due to the presence of parasites in the semen of infected dogs [4-7]. However, the L. infantum tropism to the canine genital system is still a controversial question. Here, we report a case of orchitis in a leishmaniotic dog associated with the presence of Leishmania DNA in the testis.

\section{Case report}

A 6-yr-old male Husky was hospitalized at the Department of Veterinary Clinical Science of the Federico II University of Naples for the evaluation of a seborrhoeic, pruriginous dermatitis (Figure 1) with a history of two months of alopecia and pruritus. The dog had been treated for sarcoptic mange without any improvement. Physical examination showed an enlargement of the right testis (Figure 2). No lymphadenopathy was recorded. Routine fine needle aspiration cytology from the enlarged testis was performed by the attending pathologist. Air-dried slides were prepared, and immediately stained with May Grunwald-Giemsa Quick Stain (BioOptica, Milan). Clinical laboratory parameters were evaluated. Indirect immunofluorescent antibody test (IFAT) for Leishmania spp. was carried out, and samples from

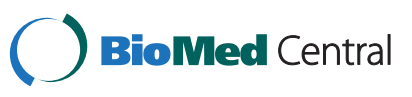




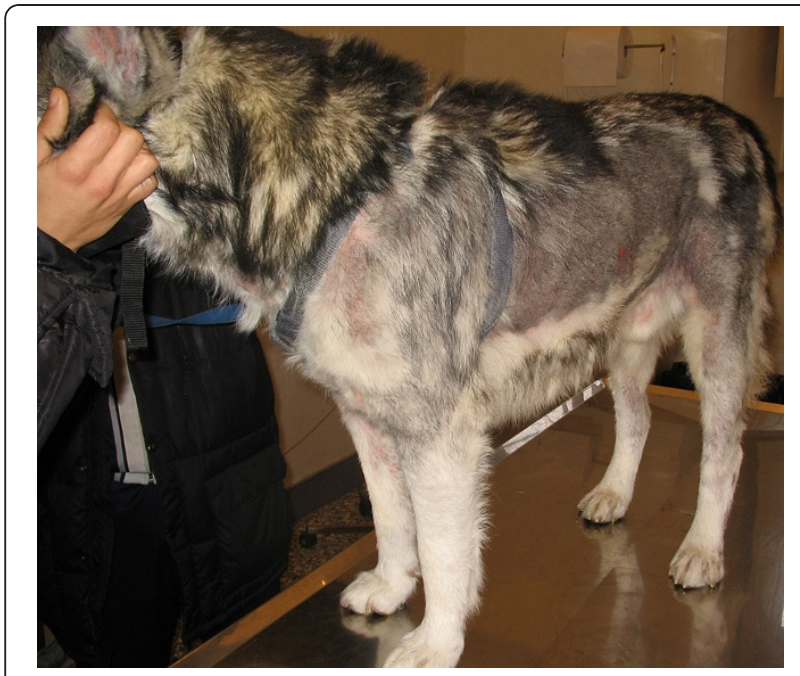

Figure 1 A 6-yr-old male Husky dog showing clear evidence of dermatitis.

blood, urine, lymph node, and testis were collected, and processed for the evaluation of Leishmania DNA load by real-time PCR assay as previously described [8].

Cytological examination of testis samples showed testicular round cells with course nuclear chromatin, single large, prominent nucleoli, and moderate amounts of basophilic cytoplasm. The presence of many inflammatory cells, such as neutrophils, with nuclear degenerative changes, several lymphocytes, plasma cells and a large number of macrophages containing intracellular Leishmania amastigotes was observed. A diagnosis of chronic orchitis due to Leishmania spp. was made. Haematological and biochemical parameters were consistent with CanL (Table 1) as demonstrated by the anemia, increased

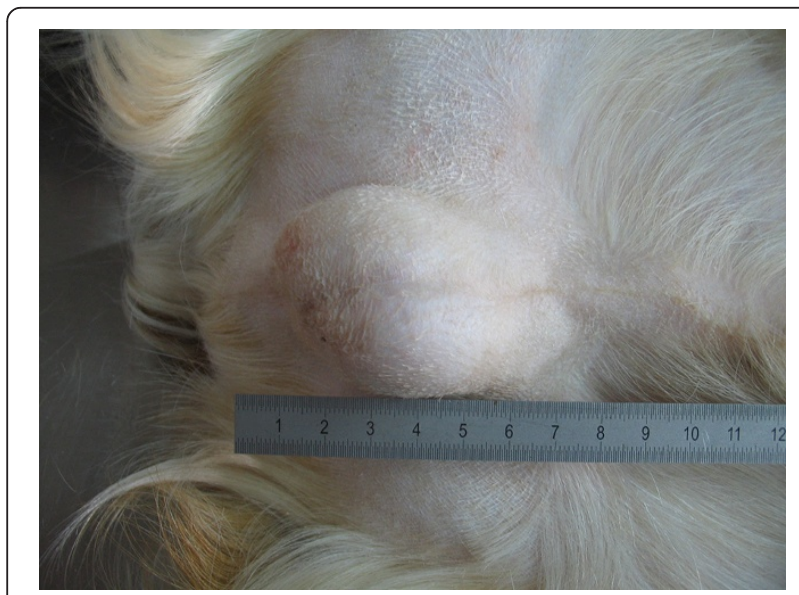

Figure 2 Evident enlargement of right testis in the Husky dog. levels of total proteins, and high UP/C ratio. $[9,10]$ Real time PCR and IFAT results confirmed the infection by L. infantum of the dog (Table 2).

The dog was treated with a combination of miltefosine [11] at a dose of $2 \mathrm{mg} / \mathrm{kg} /$ day per 28 days and allopurinol at a dose of $10 \mathrm{mg} / \mathrm{kg} /$ day for all the observation period (1 year). For follow-up assessment, biological samples were collected at the time of diagnosis (T0), and $1,2,3,6,12$ months after the treatment had started (T1, T2, T3, T6 and T12, respectively).

Before therapy, a very high parasite DNA load was detected in lymph node aspirates (23602.83 parasite DNA/ml) and testis biopsy (14406.57 parasite DNA/ $\mathrm{ml}$ ), whereas lower load values were observed in blood and urine samples (321.91 and 779 parasite DNA/ml, respectively). These results confirmed previous data on the comparative analysis of different tissues for CanL diagnosis by conventional or real-time PCR [12]. After 1 month of therapy, a progressive clinical improvement was observed, including a moderate decrease of anti-Leishmania antibody titer together with a strong reduction of Leishmania DNA load in all biological samples. However, the complete elimination of Leishmania DNA was never observed in all tissues. After the therapy, at 1 month follow-up, the cytological evaluation of the testis did not show any inflammatory cell.

\section{Conclusions}

This case report confirms that CanL can be associated with testis lesions (orchitis) in naturally infected dogs. The Leishmania amastigotes in the testis apparently act as a causing factor, triggering the inflammatory response. Experimental infection of hamsters with $L$. donovani resulted in testicular amyloidosis, degeneration, progressive atrophy, and azoospermy. In this experimental model, the degenerative changes were also associated with infiltration of lymphocytes and macrophages containing amastigotes in the testes [13]. In contrast, testicular amyloidosis was not observed in our case and in other studies [4]. In human visceral leishmaniasis, testicular involvement has not been extensively studied, but there is one study reporting amastigotes in macrophages obtained by fine needle aspiration of the testes from a boy with a severe lymphoblastic leukemia [14].

Genital involvement during visceral leishmaniosis could result in shedding of Leishmania in the semen, favoring venereal transmission of the disease, such as reported in humans [15]. Venereal and vertical transmission of L. infantum in naturally infected dogs in Germany has been reported [7]. Inflammation associated with erosions and/or ulcerations and the presence 
Table 1 Dog laboratory parameters recorded at time 0 (T0) and after 1 (T1), 2 (T2), 3 (T3), 6 (T6) and 12 (T12) months from the diagnosis

\begin{tabular}{|c|c|c|c|c|c|c|c|c|}
\hline Substrate & Parameter & TO & $\mathrm{T1}$ & $\mathrm{T} 2$ & T3 & T6 & T12 & $\begin{array}{c}\text { Normal } \\
\text { range }\end{array}$ \\
\hline \multirow[t]{11}{*}{ Serum } & Urea (mg/dl) & 45 & 47 & 29 & 31 & 28 & 26 & $25-50$ \\
\hline & Creatinine (mg/dl) & 1.65 & 1.3 & 1.26 & 1.47 & 1.48 & 1.54 & $<1.8$ \\
\hline & $\operatorname{ALT}(U \mathrm{I} / \mathrm{L})$ & 27 & 23 & 25 & 24 & 26 & 33 & $10-47$ \\
\hline & Glucose (mg/dl) & 81 & 80 & 83 & 81 & 76 & 86 & $60-110$ \\
\hline & Total proteins $(\mathrm{g} / \mathrm{dl})$ & 9.4 & 8.7 & 7.4 & 7.4 & 7.4 & 6.2 & $6-7.8$ \\
\hline & Gamma globulin (g/dl) & 3.63 & 2.84 & 2.16 & 2.16 & 2.16 & 2.84 & $0.9-2.2$ \\
\hline & Beta globulin (g/dl) & 2.39 & 2.43 & 2.31 & 0.31 & 0.31 & 0.34 & $0.6-1.4$ \\
\hline & Alpha 2 globulin (g/dl) & 0.41 & 1.55 & 1.11 & 1.11 & 1.11 & 0.82 & $0.3-1.1$ \\
\hline & Alpha 1 glubulin (g/dl) & 3.50 & 1.20 & 1.04 & 1.04 & 1.04 & 0.67 & $0.2-0.5$ \\
\hline & Albumin (g/dl) & 2.35 & 0.70 & 1.12 & 1.12 & 1.12 & 0.70 & $2.3-3.4$ \\
\hline & A/G ratio & 2.25 & 2.46 & 1.96 & 1.96 & 1.96 & 0.53 & $0.7-1.11$ \\
\hline \multirow[t]{4}{*}{ Blood } & $\mathrm{RBC}(\mathrm{x} 106 / \mu \mathrm{L})$ & 3.99 & 6.01 & 4.47 & 4.71 & 5.1 & 5.2 & $5.6-8.6$ \\
\hline & $\mathrm{Hb}(\mathrm{g} / \mathrm{dL})$ & 9.9 & 11.3 & 11.6 & 12.2 & 13.5 & 16.3 & $13.5-18$ \\
\hline & WBC (x 10 3/ML) & 22.1 & 24.2 & 15.1 & 13.4 & 11.3 & 8 & $6-17$ \\
\hline & 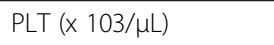 & 456 & 366 & 607 & 370 & 343 & 310 & $200-500$ \\
\hline \multirow[t]{2}{*}{ Urine } & Density (g/ml) & 1031 & 1021 & 1021 & 1015 & 1010 & 1015 & 1015-1040 \\
\hline & UP/C ratio & 5.5 & 2.4 & 2.3 & 0.3 & 0.4 & 0.1 & $<5$ \\
\hline
\end{tabular}

of amastigotes in the penis and prepuce, as well as the presence of macrophages containing amastigotes migrating through the urethral epithelium might contribute to Leishmania shedding in the semen. Although the biological vector is the most important route of transmission, the possibility of CanL venereal transmission has epidemiological significance, mostly in relation to the implementation of an eradication program. This route of transmission in dogs is particularly relevant in areas where treatment and vaccination of dogs against CanL are frequent, since under those conditions potentially infective dogs may not be readily identified, thus increasing the chance of using these dogs in reproduction, which may favor spread of the disease.

Table 2 Leishmania load (parasite DNA/ml) in blood, lymph node aspirates, urine and testis samples at time 0 (T0) and after 1 (T1), 2 (T2), 3 (T3), 6 (T6) and 12 (T12) months from the diagnosis

\begin{tabular}{lcccccc}
\hline Substrate & T0 & T1 & T2 & T3 & T6 & T12 \\
\hline Blood & 321.91 & 205 & 13 & 10 & 11 & 4.05 \\
\hline Lymph node & 23602.83 & 1694.78 & 1541.89 & 4.95 & 10 & 2.02 \\
\hline Urine & 779 & 178 & 80 & 30 & 10 & 3.0 \\
\hline Testicle & 14406.57 & 116.26 & 2.88 & 2.18 & 3.05 & 10.64 \\
\hline IFAT & $1: 1280$ & $1: 640$ & $1: 1280$ & $1: 80$ & $1: 160$ & $1: 320$
\end{tabular}

Competing interests

The authors declare that they have no competing interests.

\section{Authors' contributions}

LM conceived the study, participated in the design, data collection, and analysis of real-time PCR study, and drafted the manuscript. OP performed cytological analysis of testis tissues. RDM participated in the hematological and biochemical data collection and analysis, and cooperated in drafting the manuscript. AEG participated in the overall study design and realization. All authors read and approved the final version of the manuscript.

\section{Acknowledgements}

This work was supported by a grant from University of Naples Federico II (Italy).

\section{Author details}

'Department of Veterinary Clinical Science, University of Naples Federico II, Via F. Delpino 1, 80137 Naples, Italy. ${ }^{2}$ Department of Animal Pathology and Health, University of Naples Federico II, Via F. Delpino 1, 80137 Naples, Italy. ${ }^{3}$ Department of Biological Structures, Functions and Technologies, University of Naples Federico II, Via F. Delpino 1, 80137 Naples, Italy.

Received: 10 September 2012 Accepted: 10 September 2012 Published: 28 September 2012

\section{References}

1. Palatnik-de-Sousa CB, Day MJ: One Health: the global challenge of epidemic and endemic leishmaniasis. Parasit Vectors 2011, 4:197.

2. Wang $J Y, H a$ Y, Gao $C H$, Wang $Y$, Yang $Y T$, Chen HT: The prevalence of canine Leishmania infantum infection in western China detected by PCR and serological tests. Parasit Vectors 2011, 4:69.

3. Owens SD, Oakley DA, Marryott K, Hatchett W, Walton R, Nolan TJ, Newton A, Steurer F, Schantz P, Giger U: Transmission of visceral leishmaniasis through blood transfusions from infected English foxhounds to anemic dogs. J Am Vet Med Ass 2001, 219:1076-1083.

4. Diniz SA, Melo MS, Borges AM, Bueno R, Reis BP, Tafuri WL, Nascimento EF, Santos RL: Genital lesions associated with visceral leishmaniasis and 
shedding of Leishmania sp. in the semen of naturally infected dogs. Vet Pathol 2005, 42:650-658.

5. Silva F, Rodrigues AAM, Rego IOP, Santos RLH, Oliveira RG, Silva TMA, Xavier MN, Nascimento EF, Santos RL: Genital lesions and distribution of amastigotes in bitches naturally infected with Leishmania chagasi. Vet Parasitol 2008, 151:86-90.

6. Silva FL, Oliveira RG, Silva TM, Xavier MN, Nascimento EF, Santos RL: Venereal transmission of canine visceral leishmaniasis. Vet Parasitol 2009, 160:55-59.

7. Naucke TJ, Lorentz S: First report of venereal and vertical transmission of canine leishmaniosis from naturally infected dogs in Germany. Parasit Vectors 2012, 5:67.

8. Manna L, Reale S, Viola E, Vitale F, Foglia MV, Pavone LM, Caracappa S, Gravino AE: Leishmania DNA load and cytokine expression levels in asymptomatic naturally infected dogs. Vet Parasitol 2006, 142:271-280.

9. Manna L, Reale S, Picillo E, Vitale F, Gravino AE: Urine sampling for realtime polymerase chain reaction based diagnosis of canine leishmaniasis. J Vet Diagn Inv 2008, 20:64-67.

10. Mugasa CM, Thierry L, Schoone GJ, Basiye FL, Saad AA, el Safi S, Kager PA, Henk DFH S: Simplified molecular detection of Leishmania parasites in various clinical samples from patients with leishmaniasis. Parasites \& Vectors 2010, 3:13.

11. Manna L, Reale S, Vitale F, Picillo E, Pavone LM, Gravino AE: Real-time PCR assay in Leishmania-infected dogs treated with meglumine antimoniate and allopurinol. Vet J 2008, 177:279-282.

12. Manna L, Vitale F, Reale S, Caracappa S, Pavone LM, Della Morte R, Cringoli G, Staiano N, Gravino AE: Comparison of different tissue sampling for PCR-based diagnosis and follow-up of canine visceral leishmaniosis. Vet Parasitol 2004, 125:251-262

13. Gonzalez JL, Gallego E, Castaño M, Rueda A: Testicular amyloidosis in hamsters experimentally infected with Leishmania donovani. Br J Ex Pathol 1983, 64:518-523.

14. Kapila K, Prakash MB, Mehrota R, Vermar K: Testicular leishmaniasis in a boy with acute lymphoblastic leukemia. Acta Cytol 1994, 38:878-879.

15. Symmers WSC: Leishmaniasis acquired by contagion: a case of marital infection in Britain. Lancet 1960, 16:127-132.

doi:10.1186/1756-3305-5-216

Cite this article as: Manna et al: Detection of Leishmania parasites in the testis of a dog affected by orchitis: case report. Parasites \& Vectors $20125: 216$

\section{Submit your next manuscript to BioMed Central and take full advantage of:}

- Convenient online submission

- Thorough peer review

- No space constraints or color figure charges

- Immediate publication on acceptance

- Inclusion in PubMed, CAS, Scopus and Google Scholar

- Research which is freely available for redistribution 